\title{
A Study on General Education in Local Institutions of Higher Learning
}

\author{
$\operatorname{Lin} \operatorname{Lin}^{1, a}$ \\ ${ }^{1}$ Institute for Higher Education, Jilin Agricultural University,Changchun,130118, China \\ aemail: linlinjlau@126.com
}

Keywords: Local institutions of higher learning; General education; General education curriculum

\begin{abstract}
General education has become an important part of higher education in all countries which is an effective way to improve students' comprehensive literacy and cultivate students International vision and spirit of creation. This paper expounds on connotation, significance and status of the current general education, and puts forward reform suggestions concerning the existing problems.
\end{abstract}

\section{Introduction}

General education is an important link of undergraduate education to develop citizens and spread common values. In recent years, a wide attention has been drawn from educational scholars and institutions of higher learning towards general education. Gradually, general education has been an effective approach to improving students' comprehensive qualities and enhancing their innovational spirit. This paper adopts local institutions of higher learning as research objects. Based on analysis of their general educations status, problems existing in their general education curriculum construction are pointed out. Referring to experiences of key institutions of higher learning, this paper puts forward core curriculum system construction models for general education of local institutions of higher learning and corresponding guarantee mechanisms.

\section{Concept analysis of general education}

General education is a kind of education, whose purpose is to endow students with knowledge and values to survive in different circles of people in the modern diversified society. In the early $19^{\text {th }}$ century, Professor A.S. Parkard from Bard College in US connected it with university education for the first time ever. Later, an increasing number of scholars studied it and achieved fruitful research findings. In the mid-1980s, Taiwan scholars, proceeding from traditional Chinese education, translated general education into "Gneral Education”.

\section{Significance of implementing general education in local institutions of higher learning}

General education as the soul of university education

University education should not be restricted to education of certain skill. Aiming at bringing up "all-rounders", it must shift from knowledge education to emotion education, moral education and humanity education. Local institutions of higher learning should gear their general education to requirements of local economic and social development by developing students with solid professional skills and application abilities. The soul of university education is to cultivate "all-rounders" with a healthy personality and fully receiving moral, physical and intellectual education. The difference between university education and vocational education is that the former goes far beyond skill education. Though local institutions of higher learning are in principal capitals or cities below, their talent development vision should focus on the whole society. Local institutions of higher learning are universities in the modern sense. Implementation of general education is a mission of modern university education ${ }^{[1]}$.

General education as a way to bring up "all-rounders”

Years of test-oriented education has distorted knowledge structure of contemporary university 
students. General education is an ideal way to promote their all-around learning and balance their knowledge structure. At present, lack of social common sense, lack of knowledge outside the scope of their major and lack of knowledge about human relations and emotions have become a social phenomenon. If students cannot make up their knowledge gap in the university period, their future development might be impeded.

General education as an effective way to bring up "quality talents”

Many people often sign at failures of contemporary universities to bring up masters. An important reason is that students' knowledge structure is too professionalized, their thinking is stereotyped and their knowledge of different fields is lacking. Researchers have found out that knowledge of different subjects is complementary and mutual-reinforcing. Art and science, cultural knowledge and scientific knowledge are interconnected and mutual-promoting. Interdisciplinary knowledge and multi-aspect thinking are the basis to bring up masters. General education can allow students to learn knowledge and methods of different disciplines and integrate their interdisciplinary knowledge. Thus, general education is the best way to discover outstanding talents.

General education as a way to build a learning society, an innovative society and a harmonious society

Through general education, all-rounders with an aggressive and innovative spirit and comprehensive knowledge can be developed. Such talents can adapt themselves to the current employment system reform and the frequent job-hopping status. Guided by the concept of general education, local institutions of higher learning will focus on shaping talents equipped with both cultural and scientific knowledge, reasonable thinking and operational abilities. Many social problems can be addressed through implementation of general education. Moreover, talents can contribute more to society with their abilities. In this way, China can accelerate its building of a socialist harmonious society.

\section{Analysis of general education status in institutions of higher learning and corresponding causes}

Weak awareness of the concept of general education

General education courses are often regarded as insignificant courses. Time for general education courses is squeezed, putting general education at a marginalized place. In the eyes of teachers and students, the top priority is to master a professional skill, which is also the ultimate goal of employment. Therefore, there is a popular belief among them, that is, general education courses are of no help to their future employment. All in all, the concept of general education lacks sharpening among university teachers and students.

Overemphasis on specialized courses

During curriculum construction, students' operational abilities are overemphasized. Specialized courses are often the top priority, occupying too much time and credits of students' development program. There is little room for development of general education, which takes difficulty to inch forward ${ }^{[2]}$. Apart from required courses of the Ministry of Education, local institutions of higher learning have freedom in setting other courses. Moreover, when arrangement of specialized courses is impeded by general education courses, the latter often has to give way to the former.

Serious lack of general education teachers

In most institutions of higher learning, due to inadequate attention paid to general education, the faculty resources for general education are also fewer. Most teachers are not chosen for specialized courses. These teachers do not have too many teaching experiences, so they fail to provide quality general education courses for students, let alone to develop students' ability to integrate knowledge of sciences and liberal arts.

Unclear objectives of general education

Local institutions of higher learning should aim at developing talents with an innovative and entrepreneurship spirit and integrated development in terms of skills, morals, intelligence and physically. General education is not to match up credits. It should be adopted as a means to develop 
students' interdisciplinary thinking and innovative thinking. Through general education, students should be capable of communication between different cultures and subjects.

\section{Suggestions for reform of general education courses in institutions of higher learning}

Sharpen the awareness of general education concept and curriculum

The purpose of the educational curriculum system construction is to realize unity of sense and sensibility, unity of personality and knowledge, and unity of physical health and psychological harmony. Local institutions of higher learning should be clear that the curriculum system construction of general education is not a casual match of different subjects and courses, just an interconnected and logically sensible organic system combination with certain structural functions. To shape the general education curriculum into a systematic whole, local institutions should not only fully learn the knowledge demands, spiritual pursuits and ideological connotation of "all-rounders", but also efficiently classify general education courses in the field of humanities, social sciences and so on.

Clarify teaching goals

The division of the general education goals should focus on improvement of overall qualities and basic abilities of students instead of one-way knowledge infusion. To build a clear and comprehensive teaching goal system is a must to realize reform of general education in institutions of higher learning ${ }^{[3]}$. Formulation of goals should be based on China's national conditions and conditions of universities themselves. Under the guidance of an overall goal, goals of various levels can be formulated, thus achieving further detailing of the overall goal and promoting realization of teaching goals of general education.

Optimize general education curriculum

Realization of general education goals cannot be separated from setting and effective implementation of general education courses. First, the curriculum setting must be based on practical conditions and reflect the ultimate goal of general education curriculum. Second, in terms of curriculum selection, a peer review should be held in institutions of higher learning, abandoning the casual curriculum application form and fundamentally guaranteeing curriculum quality. Third, in terms of curriculum content, profoundness, accuracy and strictness should be emphasized. Besides, there should be scientific standards for curriculum setting so as to guarantee scientificness and standardability of curriculum setting and form a systematic and effective curriculum system.

Enhance faculty construction

Choose some teachers interested in teaching general education for further training or exchange learning. Encourage teachers to cooperate with each other to form a teaching team. In this way, the tiredness of designated teachers to teach the same courses at a fixed time in the long term can be avoided. Besides, resources in and off campus should be integrated. Some experienced teachers can be employed to develop boutique courses ${ }^{[4]}$. Under the prerequisite of guaranteeing teaching quality and teaching effects, convenience and support can be provided for teachers in terms of teaching forms so as to create favorable conditions for expansion of the general education faculty.

Set specialized management institutions

Set up specialized management institutions to design and manage general education courses. Institutions of higher learning should attach great emphasis to general education, and facilitate reform of general education in terms of policy support and capital input ${ }^{[5]}$. From the perspective of theoretical exploration, implementation, effect evaluation and system construction, specialized institutions in charge of general education, including teaching research offices, management centers or independent colleges, can be set up to achieve independent and scientific development of general education in institutions of higher learning.

Improve supporting systems for implementation of general education courses

Institutions of higher learning should formulate effective capital use provisions based on practical conditions so that every link, including capital appropriation, supply and use, has rules to follow and the capital chain for the general education curriculum system can be guaranteed. In order to guarantee teaching quality of general education, institutions of higher learning should improve 
their general education quality monitoring and evaluation systems to include more subjects and levels, and to conduct a more comprehensive and objective evaluation of their general education curriculum teaching effect.

\section{Conclusion}

In recent years, the concept of general education emphasizing on all-around development has drawn more attention from institutions of higher learning. Enhancement of general education can help develop students into all-around "social persons" advocating science and democracy, pursuing truth and justice, respecting others and good at communicating. It is necessary for local institutions of higher learning to regard general education as the soul of university education, change their school running concepts, improve teaching conditions and reform curriculums based on the "all-rounder" education at the core of general education and effectively manage and implement general education. By doing so, they can realize talent development goals expected of university education.

\section{References}

[1] Lu Wuxia. Transformation of higher vocational undergraduate talents training in local application oriented Undergraduate Education [J]. Jiangsu Higher Education ,2012(3).

[2] Li Ruifu. Research on flipped classroom teaching mode in general course of University [J]. Educational Information Technology,2015(7).

[3] $\mathrm{Yu}$ Jianwei. The practice and research of general education in Ningbo University [J]. China University Teaching, 2007(8).

[4] Lu Xuezhu. The current situation and Countermeasures of the construction of general education core curriculum in Ningbo University [J]. Journal of Ningbo Institute of Education, 2014(16).

[5] Li Huijie. Thoughts on the construction of general education curriculum system in Local Undergraduate Colleges [J]. Education Teaching Forum,2013(2). 